\title{
New species of Anthurium (Araceae) from the Peruvian
}

\author{
ANDES \\ Jorge Lingán ${ }^{1} \&$ Thomas B. Croat ${ }^{2}$
}

\begin{abstract}
(New species of Anthurium (Araceae) from the Peruvian Andes) Five new species of Anthurium are described from Peru: Anthurium chinchipense Croat \& Lingán, A. hamiltonii Croat \& Lingán, A. magdae Croat \& Lingán, A. mariae Croat \& Lingán, and A. piurensis Croat \& Lingán.
\end{abstract}

Key-words: new species, Anthurium, Peru, Andes.

Resumo

(Novas espécies de Anthurium (Araceae) nos Andes peruanos) Neste trabalho são descritas cinco novas espécies para o Peru: Anthurium chinchipense Croat \& Lingán, A. hamiltonii Croat \& Lingán, A. magdae Croat \& Lingán, A. mariae Croat \& Lingán e A. piurensis Croat \& Lingán.

Palavras-chave: novas espécies, Anthurium, Peru, Andes.

\section{INTRODUCTION}

This is one of several anticipated papers dealing with Peruvian Araceae. The authors have embarked on the preparation of an updated checklist of the Peruvian Araceae since the checklist published in 1993 by Lois Brako and Jim Zarucchi (Croat 1993) is already out of date and many more new species are yet to be described. Among the areas yet to be reported on is Oxapampa which is currently the focus of investigations by Rodolfo Vásquez (Missouri Botanical Garden) and his Peruvian colleagues. The senior author has made a thorough revision of the Araceae of the Oxapampa region and has discovered a number of new species of Araceae. During a recent two month long research trip to the Missouri Botanical Garden we were able to separate and determine many previously undetermined plants and some of these proved to be undescribed, including those reported in this manuscript.

Anthurium chinchipense Croat \& Lingán, sp. nov. Type: Peru. Cajamarca, Huarango, San Martín del Chinchipe, 5¹9'17"S, 7841'05"W, 900 m, 14 Sep. 1999, Campos et al. 6200 (holotype, MO; isotypes, $\mathrm{B}, \mathrm{K}$, NY, US, USM). Fig. 1a.

Planta terrestris; internodia usque ad 2 cm longa, 0.9-2 cm diam.; petiolus 23.2-70.2 cm longus, $0.4-0.6 \mathrm{~cm}$ diam.; lamina 24-52 $\mathrm{cm}$ longa, 14.4-37.4 cm lata, cordatosagitata; lobulas posterioribus (6.4) 7.8-15 cm longus; nervis primariis lateralibus 6-8 utroque; pedunculus $10.3-22.7 \mathrm{~cm}$ longus, $0.3-0.4 \mathrm{~cm}$ diam.; spatha viride, $7.3 \mathrm{~cm}$ longa, $1.1 \mathrm{~cm}$ lata; spadix cinereo-viride, 8.3$10 \mathrm{~cm}$ longus, $1.1-7 \mathrm{~cm}$ diam.

Description based on dried material. Terrestrial; roots 1-4 $\mathrm{mm}$ diam., white to gray, short pubescent; stems short; internodes up to $2 \mathrm{~cm}$ long, $0.9-2 \mathrm{~cm}$ diam., terete; cataphylls $7.2-9.9 \mathrm{~cm}$ long, subcoriaceous, triangular-lanceolate, brown to reddish brown, promptly withering into a mass of pale brown to reddish brown fibers. Leaves erect; petioles $23.2-70.2 \mathrm{~cm}$ long, $0.4-0.6 \mathrm{~cm}$ diam., (0.9) 1.2-1.5 times longer than the blade, U-shaped narrowly and acutely sulcate with acute margins, sometimes 2-ribbed abaxially; sheath up to $3.1 \mathrm{~cm}$ long; geniculum 1.3-2.7 cm long; blades drying subcoriaceous, $24-52 \mathrm{~cm}$ long, $14.4-37.4 \mathrm{~cm}$ wide, 1.1-1.3(1.6) times longer than wide, wider at the base, cordate-sagitate, acute to acuminate at apex, bicolorous, olive-green above, brown to reddish brown below; margins straight to slightly convex; posterior lobes elliptic, markedly convergent, directed toward the base, (6.4) 7.8-15 cm long; sinus widely hippocrepiform; midrib convex in

Artigo recebido em 09/2004. Aceito para publicação em 06/2005.

${ }^{1}$ Museo Historia Natural, UNMSM, Lima, Peru.

${ }^{2}$ Missouri Botanical Garden. P.O. Box 299. St. Loius, MO 63166-0299, USA. e-mail: Thomas.Croat@mobot.org 
both surfaces, sometimes conspicuously and narrowly acute below; primary lateral veins 6-8 per side, straight to arched-ascending, departing midrib at (30) $50-70^{\circ}$ angle; basal veins 5-10 pairs, fused all to the basal ribs; posterior ribs 3.5-11.1 cm long, recurved toward the base, naked 2.9-9.2 cm along the sinus; collective veins arising usually from the uppermost lateral veins, rarely from the $1^{\text {st }}$ pair of basal veins, $1-6 \mathrm{~mm}$ from the margins. Inflorescence erect; peduncle 10.3$22.7 \mathrm{~cm}$ long, 0.3-0.4 cm diam., green, 0.30.4 times longer than the petiole; spathe coriaceous, green, generally deciduous at fruiting, reflexed, $7.3 \mathrm{~cm}$ long, $1.1 \mathrm{~cm}$ wide, lanceolate to oblong-lanceolate, attenuate at apex, cordate at base; spadix grayish green, cylindric, $8.3-10 \mathrm{~cm}$ long, $1.1-7 \mathrm{~cm}$ diam. at base, $0.4 \mathrm{~cm}$ diam. at apex, sessile; flowers 4-lobed, margins sigmoid, $3 \times 3 \mathrm{~mm} ; 7-9$ flowers visible on the principal spiral, 6-7 flowers visible in the alternate spiral; tepals with the inner margins broadly convex, outer margins 2-sided; pistils elliptic-obovate, 2.5 $\mathrm{mm}$ long; stigmas rounded; stamens not seen. Infructescence not seen.

Anthurium chinchipense is known only from San Ignacio Province, and is endemic to the locality of San Martín del Chinchipe (thus the name "chinchipense"), at about 900 $m$ elevation in Tropical lower montane rain forest (TLM-rf) and the Tropical lower montane wet forest (TLM-wf).

The species is a member of Anthurium section Belolonchium and is distinguished by its petioles with acute margins, broadly ovate leaves, as well as by the short peduncle and generally deciduous spathe. There is a collection from the same general area (Rodríguez 1240) which represents a species that appears to be close to $A$. chinchipense, but it has a brown spadix (versus green in $A$. chinchipense), collective veins arising from the $6^{\text {th }}$ basal veins (instead of the $4^{\text {th }}$ primary lateral vein in $A$. chinchipense), and occurs up to $1240 \mathrm{~m}$ in elevation.

Anthurium chinchipense is similar to
A. macleanii Schott (which is one of two species it keys out with in the treatment of the Araceae for Peru (MacBryde 1936), but A. macleanii has the blade margin much more concave on the anterior lobe and has a longer, more tapered spadix. The other species $A$. chinchipense keys out to in the Flora of Peru is A. monzonense Engl., which differs in having longer blades $(65 \mathrm{~cm})$ that are narrowly ovate with a more or less spathulate sinus (versus triangular-sagittate with a broadly hippocrepiform sinus for $A$. chinchipense).

Paratypes: PERU. CAJAMARCA: Huarango, San Martín del Chinchipe, 5'19'17"S, 7841'05"W, 900 m, 14 Sep. 1999, Campos et al. 6208 (CAS, F, G, MO, USM).

Anthurium hamiltonii Croat \& Lingán, sp. nov. Type: Peru. Pasco, Oxapampa Province, Parque Nacional Yanachaga-Chemillén, Sector San Alberto, Refugio El Cedro, 10³3'46"S, 75²2'93"W, 2450 m, 13 Mar. 2003, J. Lingán et al. 342 (holotype, MO; isotype, HOXA). Figs. $1(b-d), 2$.

Planta terrestris vel hemiepiphytica; internodia 7-20 mm longa, 1.9-2.1 cm diam.; cataphylla 11.6-15.7 cm longa; petiolus 73.5-93.2 cm longus, 0.6-0.9 cm diam.; lamina ovata, 50-52.2 cm longa, 29.8-34.9 cm lata, cordata ad basim; nervis primariis lateralibus 6-8 utroque; pedunculus 59.5$69.7 \mathrm{~cm}$ longus, 0.5-0.7 cm diam.; spatha ovata vel lanceolata, 12.5-16.5 cm longa, $6.4-7.2 \mathrm{~cm}$ lata, viride; spadix $6.4-7.8 \mathrm{~cm}$ longus, 0.9-1.1 cm diam., flavo-virescens vel virellus.

Description based on dried material. Terrestrial to hemiepiphytic; roots $2-3 \mathrm{~mm}$ diam., whitish to grayish brown; stem terete, 1.9-2.1 cm diam.; internodes 7-20 mm long; cataphylls $11.6-15.7 \mathrm{~cm}$ long, obtusely 1ribbed, lanceolate, subcoriaceous, green to reddish, persistent as reddish brown to dark brown fibers. Leaves erect to spreading; petioles 73.5-93.2 cm long, 6-9 mm diam., terete to slightly sulcate, green; sheath $3.9 \mathrm{~cm}$ 


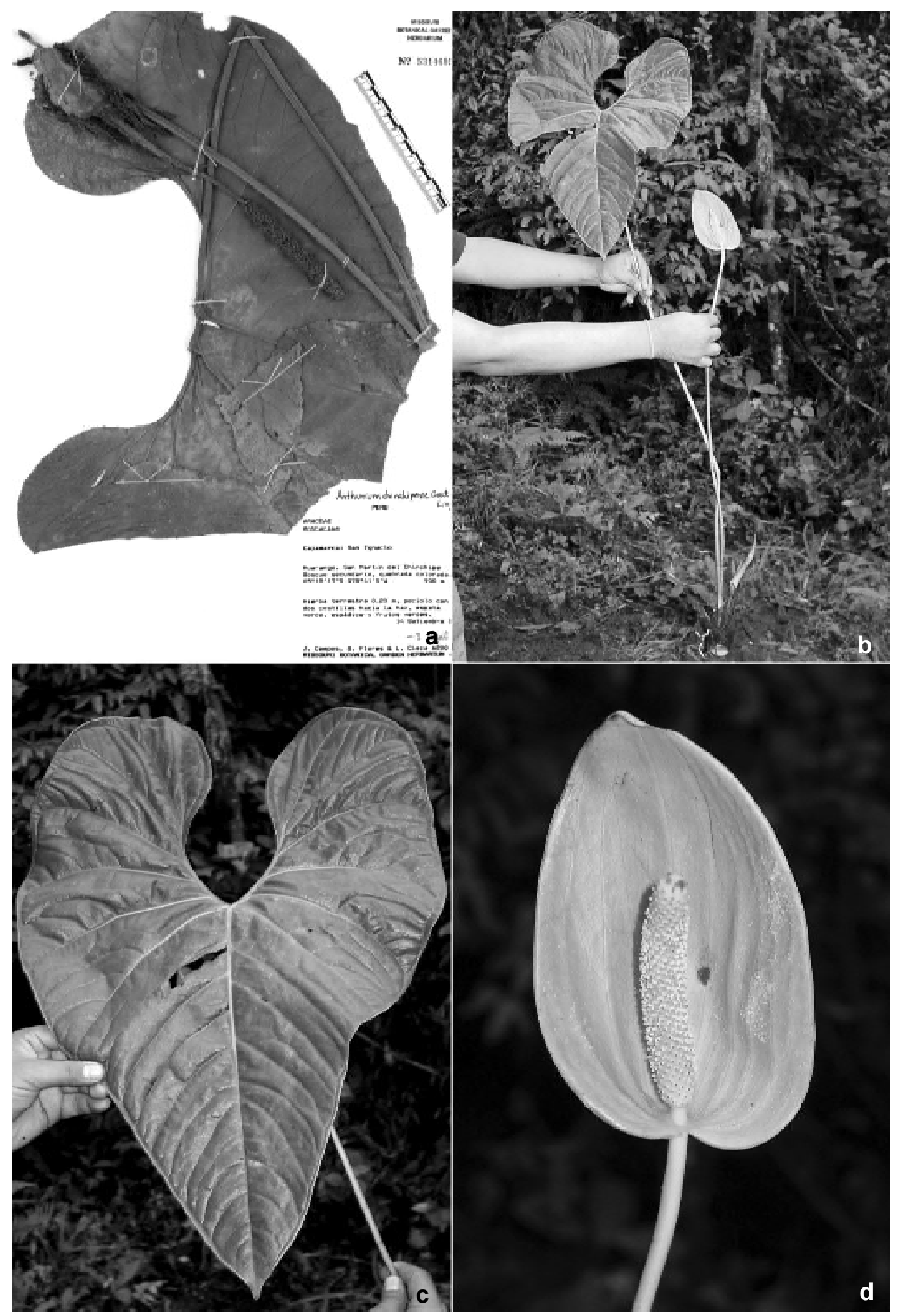

Figures 1 - a. Anthurium chinchipense Croat \& Lingán. Type specimen. (Campos et al. 6200); b-d. Anthurium hamiltonii Croat \& Lingán; b. habit; c. leaf; d. inflorescence at anthesis, note the cylindric spadix subtended by the broad spathe. (Lingán et al. 342)

Rodriguésia 56 (88): 43-51. 2005 


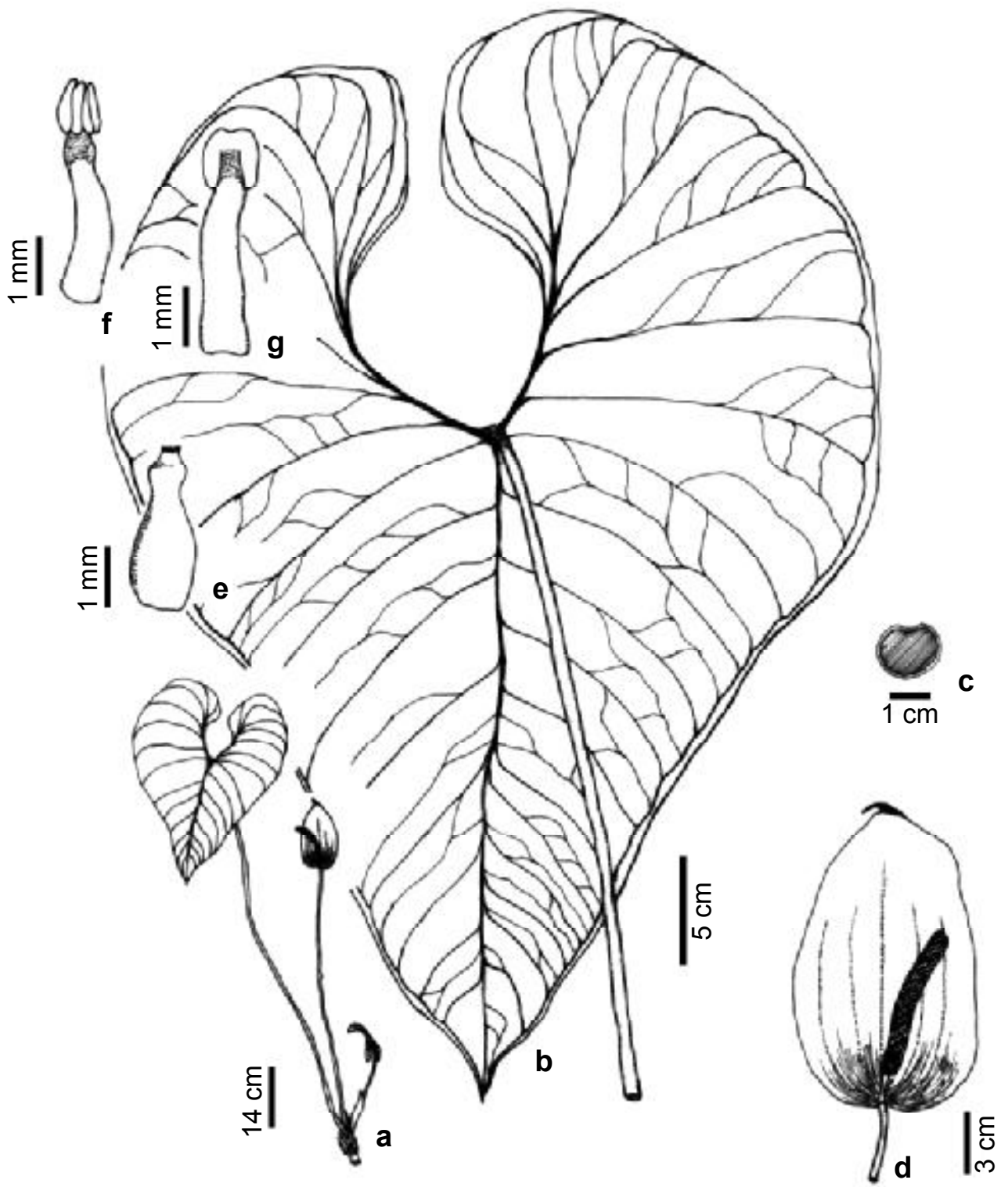

Figure 2 - Anthurium hamiltonii Croat \& Lingán. a. Habit; b. leaf (abaxial view); c.petiole (cross section); d. inflorescence; e. pistil; f. stamen (anterior view); g. stamen (posterior view). Drawing by J. Lingán, based on several collections including Soukup 2328 (GH), C. Diaz et al. 3258 (MO) and Monteagudo et al. 4507 (MO).

long; geniculum 1.2-1.4 cm long; blades subcoriaceous, drying papiraceous, 50-52.2 cm long, 29.8-34.9 cm wide, ovate, acuminate to apex, deeply cordate at base, darker and semiglossy above, slightly paler and matte below; posterior lobes oblong, convergent, 16.9-19.1 cm long, sinus rhombic to spatulate; midrib convex on both surfaces; primary lateral veins $6-8$ per side, more conspicuously convex below, arcuate- ascending, departing midrib at $30^{\circ}-50^{\circ}$; basal veins $7-8$ pairs, the $1^{\text {st }}$ to $6^{\text {th }}$ or $7^{\text {th }}$ coalesced; posterior rib $8.3-8.7 \mathrm{~cm}$ long, curved, naked $6.3-6.7 \mathrm{~cm}$ along the sinus; collective veins arising from the $4^{\text {th }}$ or $5^{\text {th }}$ pair of basal veins, 1-6 $\mathrm{mm}$ from the margin. Inflorescence erect; peduncle $59.5-69.7 \mathrm{~cm}$ long, $0.5-0.7 \mathrm{~cm}$ diam., green, $0.7-0.8$ times longer than the petiole; spathe subcoriaceous, green, persistent, erect, $12.5-16.5 \mathrm{~cm}$ long, 
$6.4-7.2 \mathrm{~cm}$ wide, broadly ovate to oblonglanceolate, hooding, abruptly acuminate to acute at apex, obtuse to rounded at base, the margins joining at approximately $170^{\circ}$ angle; spadix cylindric, $6.4-7.8 \mathrm{~cm}$ long, $0.9-1.1 \mathrm{~cm}$ diam., yellowish green to greenish; stipe greenish, $0.6-1.9 \mathrm{~cm}$ long in front, $2-3 \mathrm{~mm}$ long in back; flowers square, the margins slightly sigmoid, 4' $4 \mathrm{~mm}$; 7-8 flowers visible in the principal spiral, 9-10 flowers visible in the alternate spiral; lateral tepals with the inner margins concave, the outer margin 3-sided, anterior and posterior tepals 5 -sided; pistils ca. $3 \mathrm{~mm}$ long, largely obpyriform; stigmas oblong-linear; stamens ca. $3 \mathrm{~mm}$ long, protruding ca. $1 \mathrm{~mm}$ long at anthesis; filaments flattened; anthers not convergent above the stigmas at anthesis; thecae not divaricate; pollen light yellow. Infructescence not observed.

Anthurium hamiltonii is endemic to Peru, known from the Department of Pasco in the Parque Nacional YanachagaChemillén, Sector San Alberto, as well as in the Department of Cajamarca in the Parque Nacional de Cutervo. This species prefers shady areas, but can also be found in exposed areas in Tropical Lower Montane wet forest (TLM-wf), ranging from 2400 to $2500 \mathrm{~m}$ elevation.

The species is a member of Anthurium section Belolonchium and is distinguished by its cordate long-petiolate leaves, cataphylls persistent as a dark brown mass of fibers, and broadly ovate spathe that is erect and held close to the spadix, as well as by the greenish to yellowish cylindric spadix. The species is probably closest to $A$. macleanii with which it shares cordate leaves and persistent fibrous cataphylls, but the latter has a stipitate and purplish spadix (versus yellowish green in $A$. hamiltonii). Anthurium monzonense differs in having proportionally broader and shorter lobes, a much longer petiole sheath and having a more tapered spadix.

The species is named in honor of Hamilton Beltrán at the Museo de Historia Na- tural (UNMSM), a prolific fieldworker and avid botanical collector of the Peruvian flora who has collected many Araceae.

Paratypes: PERU: CAJAMARCA: Cutervo Province, San Andres de Cutervo, Parque Nacional de Cutervo, 2400 m, 14 Mar. 1989, Díaz et al. 3258 (MO). PASCO: Oxapampa Province, Soukup 2328 (MO); Oxapampa District, near the Refugio El Cedro, 10³2'S, $75^{\circ} 22^{\prime} \mathrm{W}, 2200-2400 \mathrm{~m}, 6$ Feb. 2003, Monteagudo et al. 4507 (HOXA, MO).

Anthurium magdae Croat \& Lingán, sp. nov. Type: Peru. Cajamarca, San Ignacio Prov., trail to limit of "La Unión", 2000 m, 1 Nov. 1995, C. Diaz \& A. Torres 7832 (holotype, MO-04920427; isotype, USM). Fig. 3a.

Terrestris vel hemiepiphytica; internodia 2-10 cm longa; cataphylla (9) 12 $18 \mathrm{~cm}$ longa, persistens intacta; petiolus 49$65 \mathrm{~cm}$ longus; lamina 23-42 cm longa, 16$25.4 \mathrm{~cm}$ lata, ovato-cordata; lobus posterioribus (7.5)10-13 cm longus, (7)8-11 cm lata; nervis primariis lateralibus 3-5 utroque; pedunculus 26-45 cm longus; spatha 10-15.5 cm longa, 2-3 cm wide, viridis; spadix luteus, cylindroideus, 8.5-11 $\mathrm{cm}$ longus, $0.7-1.2 \mathrm{~cm}$ diam.

Description based on dried material. Terrestrial to hemiepiphytic climber; roots not seen; stem to $2 \mathrm{~m}$ long, terete, 1.2-1.5(2.2) cm diam.; internodes $2.7-10.2 \mathrm{~cm}$ long, pale reddish brown, semiglossy, drying finely and densely ribbed; cataphylls (9)12-18 cm long, coriaceous, persisting reddish brown, intact, lanceolate. Leaves erect to spreading; petioles (33.7) $41.8-79.2 \mathrm{~cm}$ long, drying $0.4-0.8 \mathrm{~cm}$ diam., reddish, terete, 1.2-1.7(2) times longer than blade, 1.2-2.3 times longer than peduncle, brittle, obtusely and broadly sulcate, sometimes bluntly ribbed abaxially at base, weakly glossy to matte; sheath 3.3-7 cm long; geniculum 1-3.2 cm long; blades 23-42 cm long, 16-25.4 cm wide, 1.4-1.6 times longer than wide, ovate-cordate to narrowly ovate-cordate, deeply lobed at base, acuminate at apex, drying moderately 

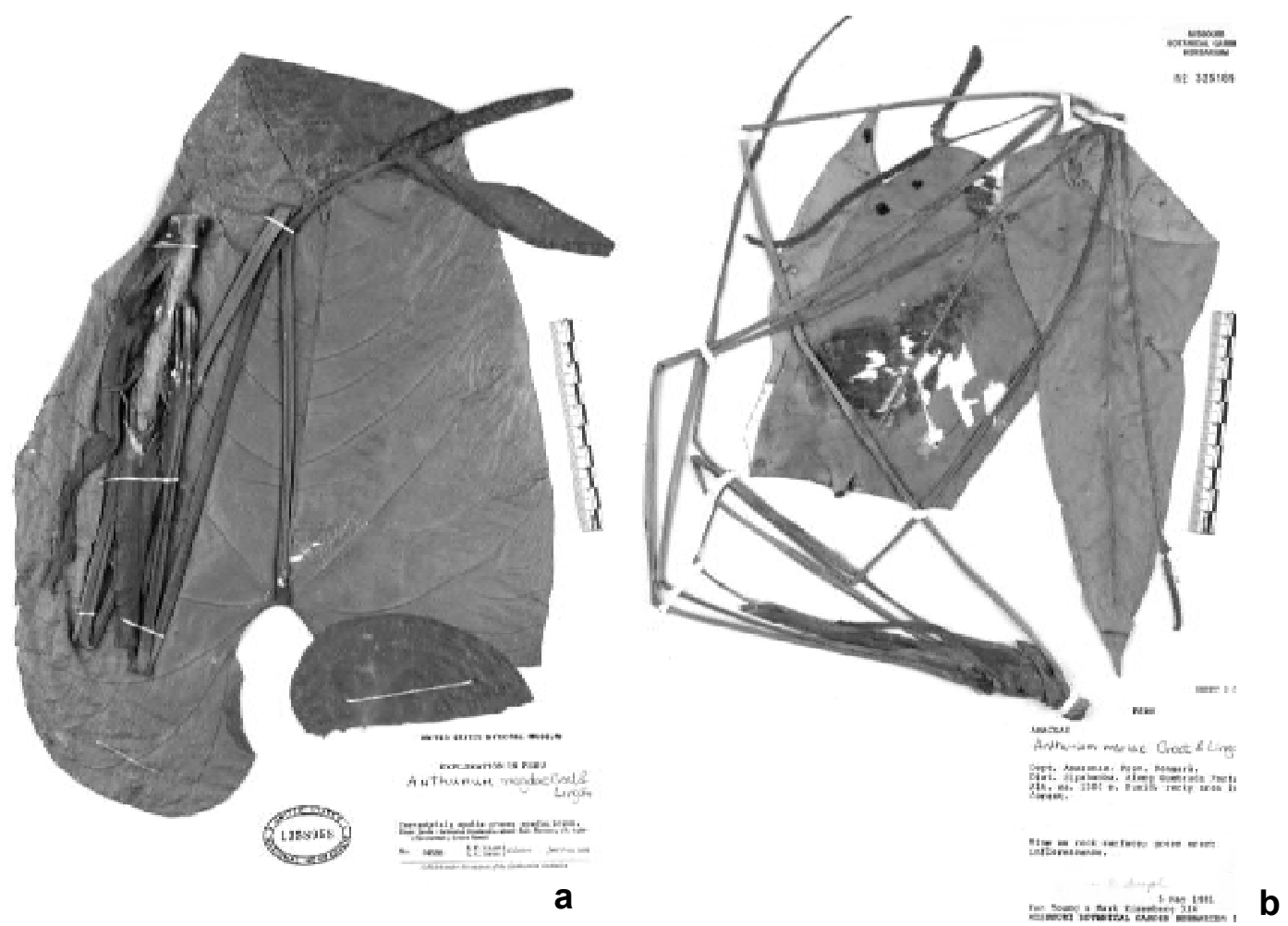

Figure 3 - a. Anthurium magdae Croat \& Lingán. Type specimen. (Díaz \& Torres 7832); b. Anthurium mariae Croat \& Lingán. Type specimen. (Young \& Eisenberg 314)

coriaceous, dark green and semiglossy above, moderately paler and glossy below, drying dark reddish brown and semiglossy above, somewhat paler and reddish brown below; anterior lobes $33 \mathrm{~cm}$ long, broadly rounded; posterior lobes (7.5)10-13 cm long, (7)8-11 $\mathrm{cm}$ wide; midrib and basal veins paler and convex above, paler and acutely raised below; primary lateral veins $3-5$, arising at an acute angle then spreading at $55-70^{\circ}$ angle, prominently arcuate to the margins; raised weakly in valleys above, those toward the apex sunken; tertiary veins darker than surface below, drying more or less prominulous below; lower surface epunctate, densely brownish speckled on drying; collective veins arising from the $1^{\text {st }}$ or $4^{\text {th }}$ pair of basal veins, extending to apex very near the margin, usually about $1 \mathrm{~mm}$ from margin but up to $4 \mathrm{~mm}$ in loop-connecting areas of primary lateral veins; basal veins 5-6 pairs, $1^{\text {st }}$ and often $2^{\text {nd }}$, sometimes $3^{\text {rd }}$ free to the base, $\left(3^{\text {rd }}\right) 4^{\text {th }}-5^{\text {th }}$ fused $(0.5) 1-3 \mathrm{~cm}$ long; posterior rib naked $1.5-2.5 \mathrm{~cm}$ along the sinus, sometimes scarcely naked at all. Inflorescence erect; peduncle $26-45 \mathrm{~cm}$ long, drying 3-4 $\mathrm{mm}$ wide; spathe green, erect-spreading, 10 $15.5 \mathrm{~cm}$ long, $2-3 \mathrm{~cm}$ wide, lanceolate to oblong-elliptic, subcoriaceous, drying reddish brown; spadix $8.5-11 \mathrm{~cm}$ long, $0.7-1.2 \mathrm{~cm}$ diam., white, broadly rounded at apex; flowers $10-11$ per principal spiral, $14-15$ per alternate spiral; flowers $1.7-2.0 \mathrm{~mm}$ wide and long; tepals broadly rounded on inner margin, 2 -sided on outside; stamens in a tight cluster around the style; anthers $0.4 \mathrm{~mm}$ long, 0.6 $\mathrm{mm}$ wide, turning light brown; thecae moderately divaricate. Infructescence not seen.

Anthurium magdae is endemic to Peru, known from Amazonas, Cajamarca and Junín Provinces in Tropical moist forest transition to Premontane (T-mf/P), at 1500$2200 \mathrm{~m}$ elevation. The species is characterized by its somewhat scandent habit, persistent intact cataphylls, terete petioles, ovate- 
cordate, reddish brown-drying, epunctate, densely brownish speckled blades, green erect-spreading spathe and white cylindroid spadix.

The species is close to A. lutescens Engl., but that species has much larger blades (to 55 $\mathrm{cm}$ long) and a distinct collective vein that does not merge with the margin (versus so close to the margin on A. magdae that it is difficult to discern). In addition, the lower blade surface of $A$. lutescens Engl. is darkpunctate whereas the lower surface of $A$. magdae is epunctate.

The species is named in honor of Magda Chanco, Curator of the USM Herbarium at the Universidad San Marcos in Lima, who has promoted and assisted the senior author in his work with Araceae.

Anthurium mariae Croat \& Lingán, sp. nov. Type: Peru. Amazonas, Bongará Province, Sipabamba District, along Quebrada Fortuna, 1300 m, 5 May 1981, Young \& Eisenberg 314 (holotype, MO; isotypes, B, K). Fig. $3 \mathrm{~b}$.

Epiphytica; internodia $1.6 \mathrm{~cm}$ longa, $1-$ $1.2 \mathrm{~cm}$ diam.; petiolus $46.6-75.4 \mathrm{~cm}$ longus; lamina 21.6-32.5 cm longa, 6.3-7.2 cm lata, anguste lanciolata, subcordata ad basim; nervis primariis lateralibus 7-12 utroque; pedunculus $41.1-64.2 \mathrm{~cm}$ longus, $0.1-0.4 \mathrm{~cm}$ diam.; spatha viridis, $2.6-5.9 \mathrm{~cm}$ longa, $0.6-$ $0.8 \mathrm{~cm}$ lata; spadix (2) 3-10.6 cm long, 0.3$0.4 \mathrm{~cm}$ diam., viride.

Description based on dried material. Epiphyte; roots white, short pubescent, 2-3 $\mathrm{mm}$ wide; internodes up to $1.6 \mathrm{~cm}$ long, $1-$ $1.2 \mathrm{~cm}$ diam.; cataphylls $3.3-11.2 \mathrm{~cm}$ long, lanceolate, subcoriaceous, persisting intact, drying brown to reddish brown. Leaves erect to spreading; petioles $46.6-75.4 \mathrm{~cm}$ long, $0.2-$ $0.5 \mathrm{~cm}$ diam., terete, green; sheath up to 3.2 cm long; geniculum 1.1-1.8 cm long; blades drying subcoriaceous, $21.6-32.5 \mathrm{~cm}$ long, $6.3-7.2 \mathrm{~cm}$ wide, narrowly ovate-triangular, attenuate at apex, subcordate at base, drying yellowish brown; midrib raised in both surfaces; primary lateral veins $7-12$ per side, not prominent above, conspicuously raised below, straight weakly curvated, departing at $50-65^{\circ}$ from the midrib; collective veins arising from the $2^{\text {nd }}$ primary lateral veins, (0.1) $0.3-1.1 \mathrm{~cm}$ from the margin. Inflorescence erect to spreading; peduncle $41.1-64.2 \mathrm{~cm}$ long, $0.1-0.4 \mathrm{~cm}$ diam., terete, green, $0.85-0.88$ times longer than the petiole; spathe subcoriaceous, green, persistent, spreading, $2.6-5.9 \mathrm{~cm}$ long, 0.6$0.8 \mathrm{~cm}$ wide, linear oblong, conspicuously acute to obtuse at apex, acute at base, the margins joining at $25-55^{\circ}$ angle; spadix long, slender and weakly tapered, (2) $3-10.6 \mathrm{~cm}$ long, $0.3-0.4 \mathrm{~cm}$ wide near to base, $0.2 \mathrm{~mm}$ wide near to apex, green; stipe green, 1.1$1.6 \mathrm{~cm}$ long in front, $0.3-0.6 \mathrm{~cm}$ long in back; flowers rhombic, margins straight, $3 \times 1.5$ $\mathrm{mm} ; 2-3$ flowers visible in the principal spiral, 4-6 flowers visible in the alternate spiral; tepals with the inner margins straight to weakly convex; pistils with stigmas rounded, not protruding; stamens with anthers protruding at anthesis; thecae divaricated. Infructescence not seen.

This species is only known from the Department of Amazonas (Province of Bongará). Anthurium mariae occurs ca. 1300 $\mathrm{m}$ in elevation, and grows near the banks of creeks in Tropical Lower Montane dry forest (TLM-df).

This species belongs to Anthurium section Calomystrium and is particularly characterized by its narrowly-lanceolate, weakly cordate leaves drying yellowish brown, cataphylls persisting entire, and slender, green spadix subtended by a subcoriaceous green spathe.

Anthurium mariae is atypical for Anthurium section Calomystrium in terms of blade shape, drying colors and type of inflorescence, but fits no other section and owing to its persistent, intact cataphylls it is best assigned to Calomystrium. It cannot be confused with another Calomystrium because other species in the section have ovate-cordate leaves and generally huge spadices (versus 
narrowly ovate-triangular with a long, slender spaidx for A. mariae).

This species is named after María Chávez, mother of the senior author.

Anthurium piurensis Croat \& Lingán, sp. nov. Type: Ecuador. Loja: Along road between Loja and San Lucas, $32.4 \mathrm{~km}$ N. of Las Juntas, along Río Marañon, 359'15"S, 7909'28"W, $1981 \mathrm{~m}, 1$ June 2003, T. B. Croat \& M. Menke 89983 (holotype, MO; istotypes B, CAS, COL, F, GB, GH, K, NY, QCNE, US, USM). Fig. 4.

Terrestris; internodia brevia, $0.2-0.5 \mathrm{~cm}$ long, 1.3-2.3 cm diam.; cataphylla (6.2) 8.7$12.4 \mathrm{~cm}$, persistens in fibras porphyreus; petiolis 42.4-58.8 cm longus, 0.4-0.9 diam., D-formatus; lamina 42.2-57.3 cm longa, 25.7$30.8 \mathrm{~cm}$ lata, ovata, profunde cordata ad basim; nervis primariis lateralibus 6-9 utroque; pedunculus $26.8-48.1 \mathrm{~cm}$ longus; spatha purpureus vel viride, $6.3-10.4 \mathrm{~cm}$ longa, 2.5-5.4 cm lata; spadix cylindricus, 3.7$12.3 \mathrm{~cm}$ longus, $0.5-1.2 \mathrm{~cm}$ diam., stipitus, purpureus.

Description based on dried material. Terrestrial; roots white, $0.2-0.5 \mathrm{~cm}$ diam.; stem terete, reddish brown; internodes short, $0.2-0.5 \mathrm{~cm}$ long, $1.3-2.3 \mathrm{~cm}$ diam.; cataphylls subcoriaceous, persisting as a pale brown to reddish brown mass of fibers, (6.2) $8.7-12.4 \mathrm{~cm}$, unribbed, lanceolate, reddish brown, weathering to a reddish brown fibers with fragments of epidermis remaining. Leaves erect to weakly spreading; petioles 42.4-58.8 cm long, 0.4-0.9 diam., D-shaped, generally bluntly 3 -ribbed abaxially; green; sheath 1.5-2.4 cm long; geniculum 1.6-2.4 cm long; blades subcoriaceous, $42.2-57.3 \mathrm{~cm}$ long, $25.7-30.8 \mathrm{~cm}$ wide, widest at the petiole insertion, ovate, semiglossy to matte on both surfaces, acuminate at apex, deeply cordate at base; margins straight to slightly convex on anterior lobe; posterior lobes oblong, convergent, $12.9-13.6 \mathrm{~cm}$ long; sinus rhombic; midrib acutely raised in both surfaces; primary lateral veins 6-9 per side, straight toward the base of the blade and

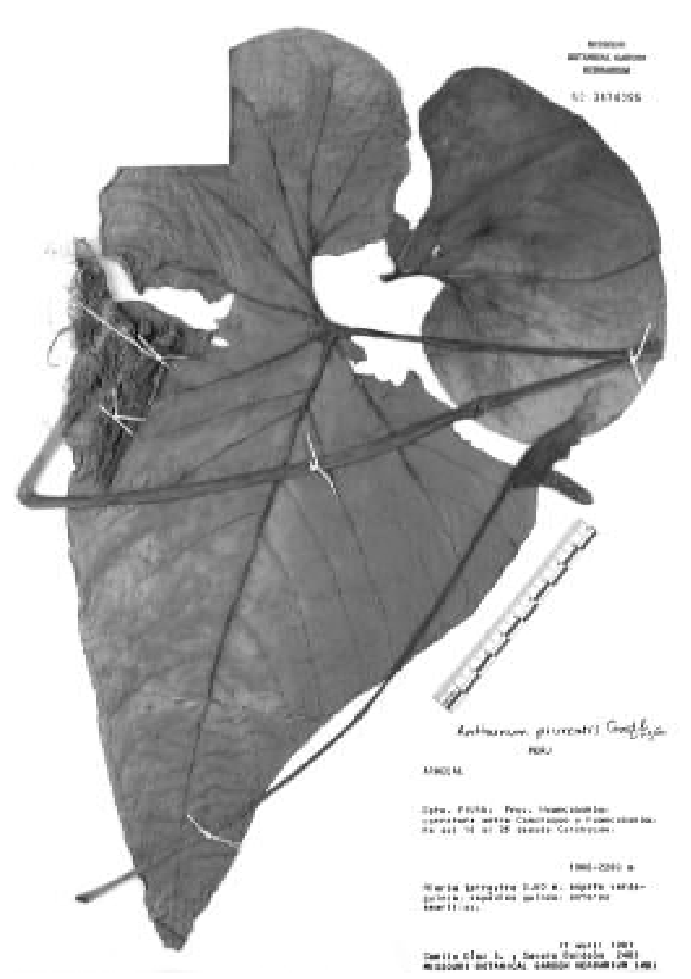

Figure 4 - Anthurium piurensis Croat \& Lingán. (Díaz \& Baldeón 2405). Paratypes specimen.

curved toward the apex, acutely raised on both surfaces, departing margins at $40-70^{\circ}$ angle; basal veins 8 pairs, $1^{\text {st }}$ and sometimes $2^{\text {nd }}$ free to the base; posterior ribs $3.5-6 \mathrm{~cm}$ long, strongly curved to the base, naked $2.1-5.5 \mathrm{~cm}$ along the margin; collective veins arising from $1^{\text {st }}$ basal veins, $2-5 \mathrm{~mm}$ from the margins. Inflorescence erect; peduncle 26.8 $48.1 \mathrm{~cm}$ long, $0.2-0.6 \mathrm{~cm}$ diam., green, $0.6-$ 0.9 times longer than the petiole; spathe subcoriaceous, purple to green, persisting, erect, hooding spadix, $6.3-10.4 \mathrm{~cm}$ long, 2.5$5.4 \mathrm{~cm}$ wide, ovate-oblong to elliptic, acute or acuminate at apex, cordate at base; spadix cylindric, $3.7-12.3 \mathrm{~cm}$ long, $0.5-1.2 \mathrm{~cm}$ diam., stipitate, purple; flowers square, margins weakly to markedly sigmoid, $2 \times 2$ $\mathrm{mm} ; 7-8$ flowers visible on the principal spiral, 5-6 flowers visible in the alternate spiral; tepals straight to slightly concave on the inner margins; pistils with stigmas elliptic; stamens protruding at anthesis; anthers conspicuously extrorse, overlapping 
the stigmas at anthesis; thecae not divaricate. Infructescence spreading; spadix $24.1 \mathrm{~cm}$ long, $2.5 \mathrm{~cm}$ diam., reddish purple; berries $0.7 \mathrm{~cm}$ long, $0.4 \mathrm{~cm}$ wide, obovate, conical at apex.

Anthurium piurensis is known from southern Ecuador (Loja Province) and Peru (Piura Dept.) ranging from 1500-2000 $\mathrm{m}$ in Tropical Lower Montane moist forest (TLM$\mathrm{mf})$.

The species is a member of Anthurium section Belolonchium and is characterized by ovate leaves with straight margins, cataphylls persisting as pale brown to reddish brown fibers, spathe hooding the spadix, and a stipitate, stubby green spadix.

The species could be confused with $A$. hamiltonii, which also has a cylindrical spadix but that species has a much longer, yellowish green spadix (versus stubby and purple in $A$. piurensis).

In the Canchaque-Huancabamba area
Díaz collected a species that looks very similar to A. piurensis, (Díaz et al. 2781), but the collective veins arise from the $4^{\text {th }}$ basal veins and extend farther than the collective veins of $A$. piurensis.

Paratypes: PERU. PIURA: Huancabamba, Canchaque-Huancabamba, 1900-2200 m, 17 Apr. 1987, Díaz \& Baldeón 2405 (MO); Canchaque, 1500-1900 m, 18 Apr. 1987, Díaz \& Baldeón 2478 (MO); between km 15 and $\mathrm{km} 25$ on rd. Canchaque-Huancabamba, 21 Mar. 1989, Díaz \& Beltrán 3372 (MO).

\section{LiTERATURE CITED:}

Croat, T. 1993. Araceae. In: L. Brako \& J. L. Zarucchi (eds.). Catalogue of the Flowering Plants and Gymnosperms of Peru. Monographs of Systematic Botany Missouri Botanical Garden 45: 71-82.

Macbride, J. F. 1936. Araceae. pp. 428-486. In: Flora of Peru. Publications of the Field Museum of Natural History, Botany Series 13. 
